FACTA UNIVERSITATIS

Series: Economics and Organization Vol. 17, № 3, 2020, pp. 261 - 273

https://doi.org/10.22190/FUEO200407019D

Original Scientific Paper

\title{
POPULATION ATTITUDES TOWARDS COMMITTING FRAUD IN SERBIAN COMPANIES
}

\author{
UDC 334.7:343.72(497.11)
}

\section{Dragomir Dimitrijević ${ }^{1}$, Dragan Cvetković ${ }^{2}$, Aleksandar Čudan ${ }^{3}$}

${ }^{1}$ University of Kragujevac, Faculty of Economics, Republic of Serbia ${ }^{2}$ Belgrade Police Directorate, Criminal Police Directorate, Republic of Serbia ${ }^{3}$ University of criminal investigation and Police studies, Republic of Serbia

\begin{abstract}
Fraud in companies, regardless of its scope and shape, creates some loss not only for the company, but very often for the wider community. Moreover, no company in the world is immune to fraud, be it small or large, in one country or another, at any level of economic and social development. Practical experience has shown that fraud, as well as damage it causes, is inevitable. For these reasons, preventing and detecting all forms of fraud in companies' operations is very important. To prevent fraud, companies need to understand what motivates people to manipulate and make financial loss. Theorists cite a number of factors that motivate fraud perpetrators to commit manipulation, but all agree that, to commit fraud, three things need to be matched: motivation, opportunity and rationalization. For this reason, the research subject in this paper is a detailed analysis of all the factors that motivate and create opportunities for people of Serbia to commit fraud in companies, as well as the most common excuses they use to justify their manipulations. We surveyed 306 respondents to analyze their motives for possible fraud, as well as their attitude on the number and forms of fraud in the business operations of Serbian companies.
\end{abstract}

Key words: motive, fraud, rationalization, opportunity, Republic of Serbia

JEL Classification: M41, M49

Received April 07, 2020 / Revised June 03, 2020 / Accepted June 22, 2020

Corresponding author: Dragomir Dimitrijević

University of Kragujevac, Faculty of Economics, Liceja Kneževnine Srbije 3, 34000 Kragujevac, Serbia

E-mail: dimitrijevicd@kg.ac.rs

๑ 2020 by University of Niš, Serbia | Creative Commons Licence: CC BY-NC-ND 


\section{INTRODUCTION}

Creating business conditions that prevent any form of fraud is a practice in the realm of utopia. Simply, no company is immune to fraud. It is possible to create an environment with satisfactory working conditions for employees and thus reduce the possibility of fraud, but fraud occurs even in such companies. The question is why fraud happens even in companies offering excellent working conditions, excellent salaries, and opportunities for promotion. The answer lies in the psychology of fraud perpetrators, so in order to prevent fraud successfully, one must look behind individuals' or groups' motives to manipulate. Research has shown that the desire to commit fraud always hides the motive to meet one's personal goal, the desire for extra money, or simply the need to prove oneself. That is why the objective of this paper is to investigate what motivates citizens of Serbia to commit fraud in companies.

\section{FRAUDS IN COMPANIES}

Fraud in companies and daily lives of people alike is nothing new. Ever since man realized that fraud can be a useful tool for achieving personal goals, fraud has become a reality. To understand fraud, one first needs a definition of fraud. Broadly speaking, fraud can be any crime using primarily deception for gain (Wells, 2004, p. 4). There is no precise legal definition of fraud. This term is used to describe acts such as deception, bribery, forgery, extortion, corruption, theft, plotting, embezzlement, misappropriation, giving false information, concealing material facts. Fraud is a deliberate deception done for the purpose of accomplishing a specific goal, or in order to harm other people (Stančić, Dimitrijević and Stančić, 2013, p. 1884). Fraud always hides a motive of an individual or several people. If the company is perpetrating fraud, then it is expected that the company itself will achieve some gain (rise in stock price, more favorable loans, attracting investors, etc.), as well as persons who enabled the company to achieve it (rise in remuneration, bonuses, shares, benefits, etc.) (Slović, 2016, p. 93). In order to understand the purpose and significance of fraud, it is first necessary to distinguish between fraud and error. Although the consequences are the same, i.e. disclosure of incorrect financial information, there is a significant difference between errors and fraud. Fraud, as opposed to error, is characterized by a conscious intention to accomplish some specific purpose and to manipulate. Fraud is typically characterized by several essential elements: misrepresentation of facts relevant to business decisions; individual's awareness that the information presented is false; person receiving information as reliable and relevant for business decision-making and the occurrence of damage as a consequence of all of the foregoing (Škarić-Jovanović, 2009, p. 25).

There are different criteria for classification of fraud, such as those related to perpetrators and victims (criminal acts of employees, criminal acts of management, investment fraud, seller fraud, customer fraud and other fraud), criteria under the criminal law, criteria related to accounting cycles (sales and billing cycles, purchase and payment cycle, payroll and staffing cycles, inventory and storage cycles, and capital acquisition cycles) and those arising from the manner of committing fraud (Petković, 2010, pp. 16-24). Nevertheless, fraud is most commonly classified into three groups: corruption, asset misappropriation and financial statements fraud. The results of a study by the Association of Certified Fraud Examiners (ACFE), conducted every two years for companies doing business in the US, indicate that the most common fraud type is asset misappropriation, and that the median loss in the case 
of this type of fraud is the lowest. On the other hand, financial statements frauds are the rarest type of fraud, but are the most dominant in terms of the average value of individual damage. The above facts are presented in Table 1 and cover the previous three surveys during the period 2014-2018.

Table 1 Classification, percent of cases and median loss

\begin{tabular}{lcccccc}
\hline Type of fruad & \multicolumn{3}{c}{ Percent of cases } & \multicolumn{3}{c}{ Median loss } \\
\cline { 2 - 6 } & 2014. & 2016. & 2018. & 2014. & 2016. & 2018. \\
\hline Asset misappropriation & $85.4 \%$ & $83.5 \%$ & $89 \%$ & $130.000 \$$ & $125.000 \$$ & $114.000 \$$ \\
Corruption & $36,8 \%$ & $35,4 \%$ & $38 \%$ & $200.000 \$$ & $200.000 \$$ & $250.000 \$$ \\
Financial statements fraud & $9,0 \%$ & $9,6 \%$ & $10 \%$ & 1 mil.\$ & $975.000 \$$ & $800.000 \$$ \\
\hline
\end{tabular}

Source: https://www.acfe.com/report-to-the-nations/2018/default.aspx

Financial statements fraud includes false balance sheets, income statements and cashflow statements of companies (Dimitrijević, 2015, p. 137). They have existed since the emergence of financial reporting, because they bring certain short-term gain to managers or owners. ACFE defines false financial reporting as "the intentional, deliberate, misstatement or omission of material facts, or accounting data which is misleading and, when considered with all the information made available, would cause the reader to change or alter his or her judgment or decision" (Zabihollah, 2002, p. 2). The most common types of damage that financial statement fraud involves include: "manipulating, falsifying, or altering accounting records or supporting documents used in the preparation of financial statements; inaccurate (fraudulent) misrepresentation or intentional omission of significant items or transactions from financial statements and intentional misapplication of accounting rules" (Stefanović, 2000, p. 4). Corruption can be defined as an act of offering, promising, giving, directly or indirectly extorting, soliciting, accepting and receiving gifts and other benefits related to the performance of duties by persons employed in the private or public sector, when such action constitutes a violation of their obligations arising from their position for the purpose of obtaining illicit property gain for themselves or others (Petković, 2010, p. 124). Asset misappropriation is generally carried out to alienate company's resources for the personal needs of the perpetrators.

\section{Motives TO COMmit FRAUd}

The question is what motivates someone to choose the dishonest way to meet their goals. The motives for fraud depend on perpetrators' goals. An individual's motive for fraud is usually based on personal goals (bonuses, job retention, promotion, etc.) or company goals (concealing losses, avoiding bankruptcy, obtaining credit, and the like). Donald Cressey, a sociologist, in his 1950s study gives the best answer to the question of what motivates fraudsters. He surveys some 200 people convicted of fraud. One of the basic conclusions he draws is that each fraud is characterized by three common factors: pressure (sometimes defined as motivation), rationalization (personal ethics), and opportunity to commit fraud (Singleton, T. et al., 2010, p. 18). The result of this study is most commonly shown by the well-known "fraud triangle" in Figure 1. 
Opportunity

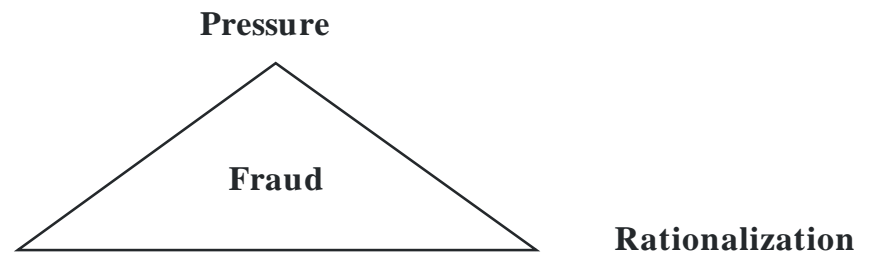

Fig. 1 Fraud triangle

Source: Coenen, T. (2008), Essentials of Corporate Fraud, John Wiley \& Sons, New York, p.10.

Pressure (motivation) usually arises as a consequence of individuals' lifestyles. Fraudsters' life events create the need for extra money or make them prove themselves, which leads to fraud. Every fraud perpetrator faces some kind of pressure. Pressure can be divided into four groups:

1. Financial pressure - practice shows that for most frauds, the pressure on the perpetrator is of financial nature. These forms of pressure usually occur suddenly in the lives of fraud perpetrators and most often as a consequence of their lifestyle. The list of possible types of financial pressure is not short and many factors are correlated (individual greed, desire for a better living standard, personal debts, poor creditworthiness, etc.);

2. Vices - this form of pressure is the worst kind of pressure because it is a consequence of the fraud perpetrators' addiction to substance abuse, gambling, alcohol etc. This form of pressure is often associated with financial pressure. In other words, financial pressure is usually a consequence of this addiction. This form of pressure causes individuals to behave very irrationally and recklessly, so that fraud caused by vices is much easier to spot and detect (Dimitrijević, 2018, p. 8);

3. Job pressure - with this type of pressure, fraudsters face a situation where they feel they have been unfairly treated at work (others have got undeserved promotion, a person is underpaid for their work, and the like). In such situations, perpetrators cause financial loss to the company. Such forms of fraud are often difficult to detect, as they are very thoroughly designed and implemented;

4. Other forms of pressure - In some circumstances, fraud can also be triggered by other forms of pressure, such as the challenge or desire to defeat internal control systems or to show one's hacking skills in mastering computer technologies by breaking through legal entities', government agencies' and banks' security systems (Petković, 2010, pp. 26-27).

The company management is most responsible for creating fraud opportunities. In other words, an environment without an adequate control system, where workers and their work and commitment are not sufficiently appreciated, creates exceptional opportunities for manipulation. Perpetrators of long-planned frauds are always waiting for the right moment to realize this opportunity, so it is difficult to detect and prove such fraud. The most important factor that creates opportunities is the lack of or poor implementation of internal controls. Practice has shown that having an effective internal control system is one of the most important steps a business can take in preventing and detecting fraud. From an audit standpoint, internal control consists of "policies and procedures that management establishes to ensure that specific client objectives are fulfilled" (Andrić et al., 2004, p. 226). The mere existence of an internal control system is not a guarantee that fraud will not occur. If this 
system is not properly implemented, there is always a certain risk that fraud will occur, especially if management does not attach sufficient importance to internal control.

Every fraud perpetrator has rationalization for his or her actions. These justifications can be very different, depending on what motives lay behind the perpetrator's fraud and manipulation. A number of studies indicate that as many as $85 \%$ of perpetrators have not previously committed a crime, so most of them have different justifications. Some of them justify themselves with a bad financial situation, some with pressure at work, but most do not see any bad intentions in committing fraud because they did not hurt anyone or wanted to return money. Others, however, believe they deserve a raise or a better job, so they simply take matters into their own hands to achieve more equitable relationship. Perpetrators cite several common justifications (Coenen, 2008, p. 10):

- "The company owes me money;

- I'm just borrowing money - I'll pay it back;

- No one will be hurt;

- I deserve more;

- It was done in good faith;

- We will arrange the papers as soon as we get out of financial difficulties, and

- Something must be sacrificed - either my honesty or my reputation."

Significantly changed circumstances in financial operations, internal control system reporting and changes in behavior and character of people in new circumstances brought the need for changes or modifications to the "fraud triangle" model, as well as for new models. The base model modifications range within three elements (a triangle), with changes initiated by different approaches and placing emphasis primarily on the act of fraud itself. This modification is based on the view that it is not sufficient to show conditions and circumstances in which fraud takes place, but that the model must also show actions that the perpetrator must take to commit fraud. This is the basis of the Fraud Element Triangle model. Theoretical research has shown that moving in a triangle is no longer sufficient to explain fraud, nor to act to prevent fraud. New standpoints result in the conception and proposals of new models. The diamond model introduces a fourth element, the ability to commit fraud. Conditions to commit fraud (fraud triangle) are not enough, as there is also the perpetrator's ability to commit fraud. This element is in some ways considered a crucial element because without the ability to commit fraud, despite the existence of three elements of the base model, the fraud may not be likely to be committed. This model also has certain modifications in theoretical proposals. Further enhancement of "geometric" models leads to a pentagon fraud model, which highlights the fifth element. In addition to the three elements of the base model, this model contains two more elements. With this model, the conditions under which fraud is committed are complemented by the characteristics of the fraud perpetrators. These are competence or the power of knowledge to commit fraud by an employee and arrogance or lack of conscience. A step further with respect to the base model and the diamond model highlights an individual's character. However, this model has also been modified so that external regulatory influence emerges as the fifth element. This element makes a transition from purely personal characteristics to external influence that has nothing to do with an individual's characteristics (e.g. audit). In addition to "geometric" models, the theory also emphasizes models created by overcoming the base model (fraud triangle), which underline other fraud elements that are not necessarily the conditions under which fraud can be not committed, nor bear the personal stamp of the perpetrator's character. These are "the Fraud Scale Model, M.I.C.E. model and Disposition Based Fraud Model” (Vukadinović, 2018, pp. 7-8). 


\section{RESEARCH RESULTS}

A survey on what motivates citizens of the Republic of Serbia to commit fraud includes 306 respondents. The targeted population was men and women aged 25 to 55 from the territory of the Republic of Serbia. The survey response rate was 51\% (306 of 600). The time period of data collection was December 2019. The electronically-distributed survey includes 15 questions, of which the first 4 are questions defining respondents' gender, age, and employment. The next 7 questions deal with the "fraud triangle" elements - motives (pressure), opportunities and rationalization, i.e. the respondents' opinion on the most common forms of the above elements. The last 4 questions consider the respondents' opinion on the most common forms of fraud in the Republic of Serbia and the activities where they occur.

If one looks at the respondents' gender structure, it can be noticed that women $(77.8 \%)$ are more dominant than men, who make up $22.2 \%$ of the total number of respondents. Also, considering the respondents' age, respondents aged 25-35 (67.8\%) and respondents aged $35-45(28.9 \%)$ dominate the sample. The results of these questions are shown in Table 2. On the other hand, regarding the respondents' employment status, the results show that the majority of respondents are employed (74.5\%). Regarding the activities in which the respondents are employed, the structure is very heterogeneous $-30 \%$ work in manufacturing companies, $24.2 \%$ in public administration, $23.3 \%$ in the financial sector and $22.5 \%$ in trade. The results of these questions can be seen in Table 3 .

Table 2 Respondents' gender and age

\begin{tabular}{ll}
\hline Respondents' gender & Respondents' age \\
\hline Women $-77.8 \%$ & $25-35-67.8 \%$ \\
Men $-22.2 \%$ & $35-45-28.9 \%$ \\
& $45-55-2.6 \%$ \\
& 55 and more $-0.7 \%$ \\
\hline
\end{tabular}

Source: author's calculation

Table 3 Respondents' employment

\begin{tabular}{ll}
\hline Respondents' employment & Respondents' activities \\
\hline Employed $-74.5 \%$ & Manufacturing companies - 30\% \\
Student $-16.7 \%$ & Public administration $-24.2 \%$ \\
Unemployed $-8.8 \%$ & Financial sector $-23.3 \%$ \\
& Trade $-22.5 \%$ \\
\hline
\end{tabular}

Source: author's calculation

The results show that $62 \%$ of the respondents have never witnessed any form of fraud (corruption, money laundering, business fraud, tax evasion...). However, $38 \%$ of respondents include a very large number of people who have witnessed fraud and wanted to confirm it. It is also true that many people in Serbia do not want to say that they have witnessed crime in fear for their safety. 


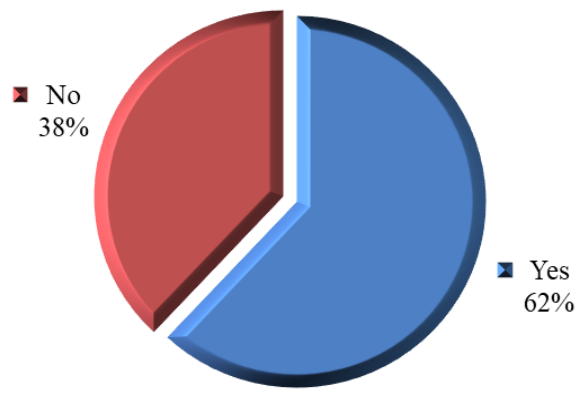

Chart 1 Have you ever witnessed fraud? Source: author's calculation

On the other hand, when asked if they would commit fraud if in a position to do so, $75.7 \%$ of respondents said no, while $24.3 \%$ said yes. When looking at the factors that would prevent respondents from committing possible fraud, the majority of respondents (of those who answered this question) state their conscience ( 24 respondents) and morality (23 respondents). Also, 13 respondents cite their family upbringing and reputation as the reason why they would not commit fraud; other reasons include ethical principles (5 respondents), fear of being fired from work (5 respondents) and personal honesty ( 2 respondents). The answers to this question are shown in Chart 2.

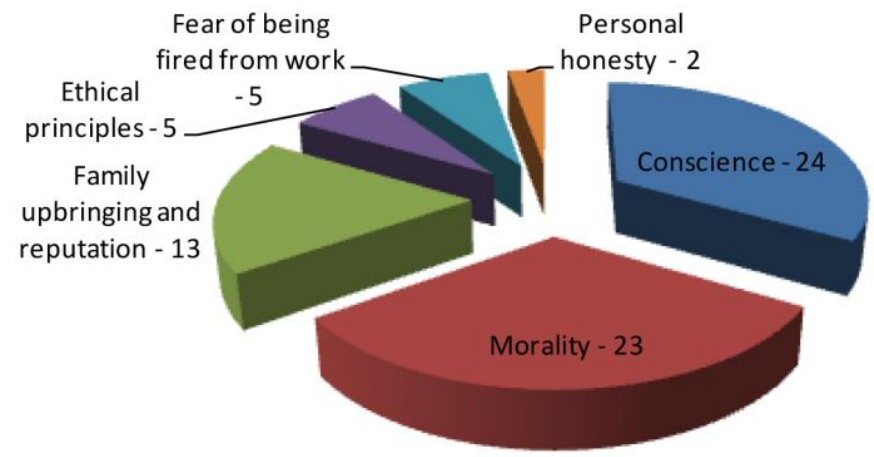

Chart 2 Reasons not to commit fraud Source: author's calculation

The following four questions concern the elements of the Donald Cressey's "fraud triangle" (pressure - motivation, opportunity and rationalization). When asked, "In your opinion, what would be the biggest pressure that would cause someone to commit fraud?", the majority of respondents point to financial pressure (51.8\%). $29.4 \%$ of respondents opt for vice as a type of pressure, $8.6 \%$ for job pressure, and $10.2 \%$ for other types of pressure (desire to prove themselves, beat the control system). It is interesting that, regarding the next question (see Chart 3), "Which of the above forms of pressure would force you to commit fraud?" most respondents also cite financial pressure as the most common type of pressure that would make them commit fraud $(55.3 \%)$, while with regard to other factors, job pressure is now in the second place $(18.7 \%)$, while vices are 
now in last place $(9.9 \%)$. This is interesting because with the previous question regarding the biggest pressure that would cause someone to commit fraud vices are in the second place with almost 30\%, and when they talk about themselves vices are in the last place.

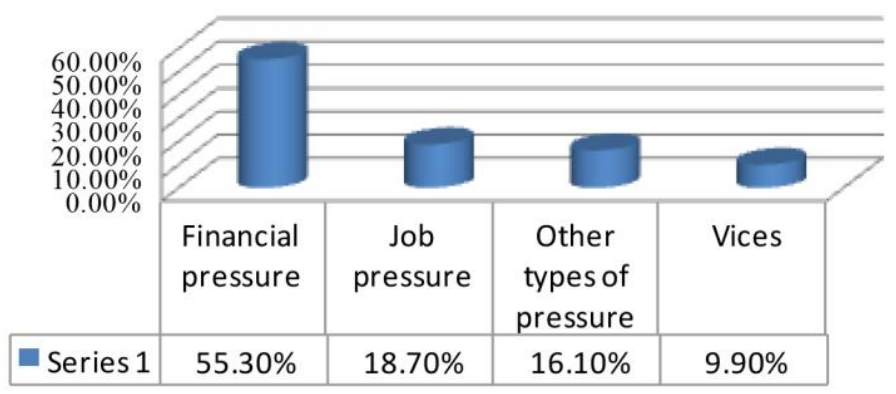

Chart 3 Pressure that would force you to commit fraud Source: author's calculation

The tenth question is about opportunities for business fraud. Survey results indicate that over 50 percent of respondents (54\%) point to the lack of a social value system as the main reason for fraud. The lack of internal control is in the second place with $25.5 \%$ of the respondents' answers, other reasons in the third with $10.9 \%$, and lack of external control in the last fourth place $(9.6 \%)$. This is interesting because employees, students and the unemployed agree on the most important factor (lack of value system), while employees do not think that internal and external controls create opportunities for fraud. It is true that $25 \%$ of employees think that lack of internal control is a factor that enables business fraud, but only $11 \%$ see lack of external control as a cause of possible fraud. This may be interpreted differently. It can be concluded that employees believe that the current form of external control is sufficient, or that that it should not even exist in its current form. Much more important is the issue of internal control, since in the Republic of Serbia only public companies and financial institutions are required by law to have this type of control. Worldwide practice has shown that the presence of internal controls largely prevents and detects business fraud. Companies in the Republic of Serbia do not have this type of control, and those that have to enforce it by law do not attach much importance to it in the fraud prevention process. Internal control in companies operating in the Republic of Serbia is mostly used to analyze the implementation of internal acts and regulations, rather than to establish a system that will prevent possible manipulation and allow employees to report possible fraud. This is precisely the factor that companies need to work on in the future if they want to prevent and detect fraud on time. It should also be noted that it is not enough to just establish an internal control system in the company, but it is extremely important to successfully implement it in all parts of the company. The results of this question are shown in Chart 4. 


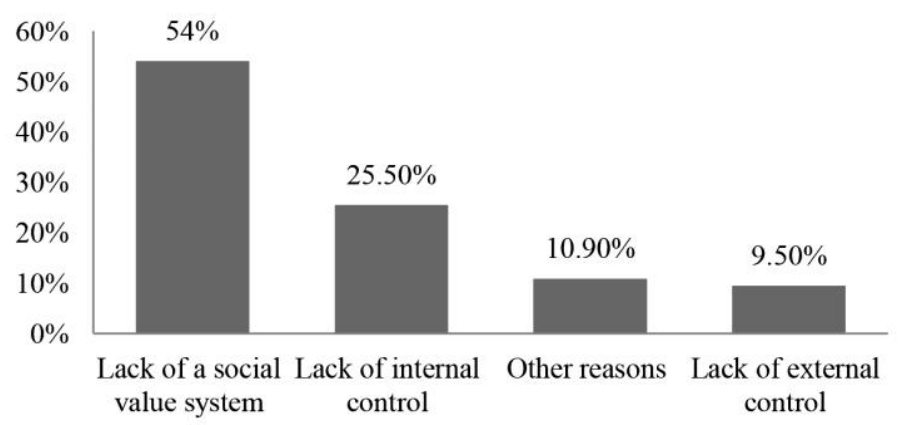

Chart 4 Opportunities for fraud Source: author's calculation

In the previous questions, the respondents had quite similar answers and some answers had the majority when viewed in aggregate and when viewed individually by different criteria (men, women, employees, students, unemployed and the like). However, with the eleventh question that refers to the justification for fraud, the respondents' answers are very heterogeneous. When asked "Which of the following factors would fraud perpetrators most use to rationalize (justify) fraud?", almost equal number of respondents said: "I deserve more" $(20.5 \%)$ and "No one will be hurt" $(20.2 \%) .15 .6 \%$ of the respondents most often said "We will arrange the papers as soon as we get out of financial difficulties", 13.6\% said "I only borrow money - I will pay it back" as the most optimal justification for the perpetrator, while for other justifications the results are as follows: "The firm owes me money" (12.6\%), "It was done in good faith" $(11.9 \%)$ and "Something must be sacrificed - either my honesty or my reputation" $(5.6 \%)$. These results can be interpreted as dividing respondents between the justifications that result from fulfilling the personal fraudsters goals ("I deserve more" and "The firm owes me money"), which together have over $30 \%$ of responses and justifications indicating that the perpetrators do not see any evil in what they did and believe they did not damage the company (over $60 \%$ of those surveyed gave these answers). The practice has shown similar results, i.e. most of those who have committed business fraud in companies around the world feel that they have not harmed anyone in their actions and that what they have done is the result of a need to fulfill their personal goals. The results of this question are given in Chart 5.
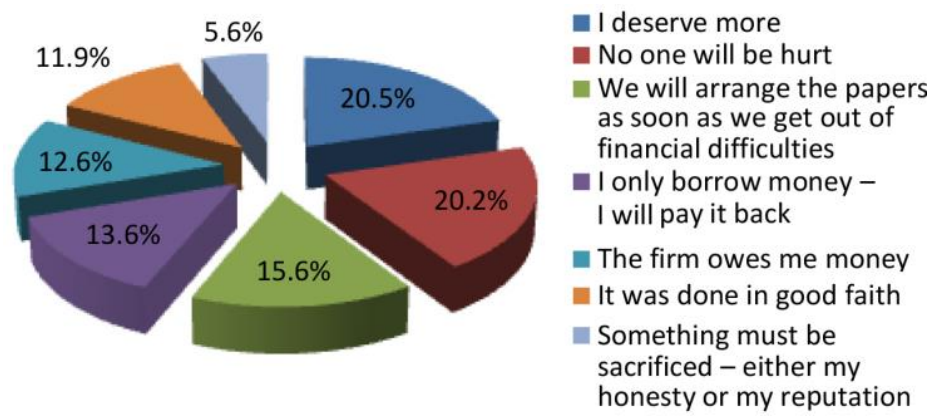

Chart 5 Justifications for fraud Source: author's calculation 
After considering the elements of the "fraud triangle", the research has placed emphasis on the respondents' opinion of the most common form of fraud in the Republic of Serbia and the activity in which fraud is most common. The twelfth question in the survey looks at the most common form of business fraud, and the results indicate that citizens label corruption as the most dominant form of manipulation in the Republic of Serbia (57.8\%), followed by money laundering with $17.3 \%$, tax evasion with $14.7 \%$, while financial statements fraud, with $8.2 \%$, and asset misappropriation (2\%) are forms of fraud that citizens believe do not occur so often in companies. These results are a bit different from the research results conducted by the Association of Certified Fraud Examiners (ACFE) over the past ten years around the world, where asset misappropriation is the most common form of fraud, prior to corruption and false financial reporting. The results of this poll indicate that citizens of the Republic of Serbia believe that corruption is deeply rooted in the systemic values of society and that a wide range of public and private institutions must fight together in order to reduce this form of fraud to a great extent, if not eradicate it. Also, the survey results indicate that citizens do not consider financial statements fraud to be dominant, but it should be borne in mind that in practice this form of manipulation not only creates the greatest financial losses but is also the most difficult to detect and prevent. Because many citizens are unaware of the dangers of this type of fraud, it is necessary to educate citizens more about the harms of financial statements fraud to the wider community directly or indirectly. On the other hand, in answering the next question, the persons interviewed indicated the activity which, in their opinion, has the most frequent business frauds. The respondents believe that public administration is characterized by common manipulation with $69.8 \%$, followed by the financial sector with $13.8 \%$, trade enterprises with $10.5 \%$ and last but not least manufacturing companies with $5.9 \%$. Since, in the opinion of the respondents, the most prevalent frauds occur in public administration, the next question addressed the public administration sector subject to fraud. The citizens believe that public companies are most sensitive to manipulation (45.9\%). This is followed by healthcare with $25.9 \%$, police with $18 \%$, public administration with $6.6 \%$, education with $3 \%$ and the military with $0.7 \%$. This question did not emphasize the form of fraud, but since the respondents indicated in the previous question that they considered corruption to be the most dominant form of fraud, it is assumed that they also believed corruption to be present in these sectors of public administration. Chart 6 indicates the opinion on the structure of fraud dominance, while Table 4 indicates the activities and sectors of public administration in which fraud occurs.

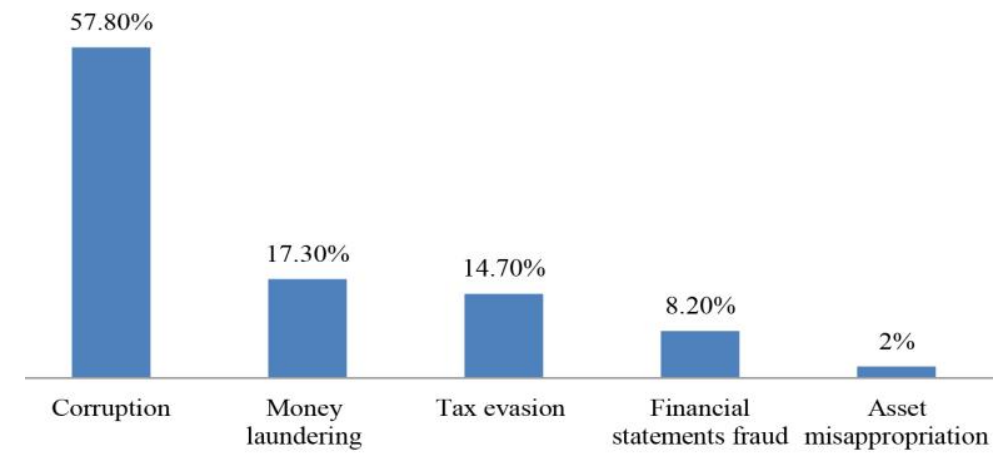

Chart 6 Most dominant forms of fraud Source: author's calculation 
Table 4 Activities and sectors of public administration where fraud is present

\begin{tabular}{ll}
\hline Activities & Sectors of public administration \\
\hline Public administration $-69.8 \%$ & Public companies $-45.9 \%$ \\
Financial sector $-13.8 \%$ & Healthcare $-25.9 \%$ \\
Trade $-10.5 \%$ & Police $-18 \%$ \\
Manufacturing companies $-2 \%$ & Public administration $-6.6 \%$ \\
& Education $-3 \%$ \\
& Military $-0.7 \%$ \\
\hline
\end{tabular}

Source: author's calculation

The last question in the survey deals with techniques for preventing business fraud. Survey results indicate that respondents believe that penal policy (54.6\%) is the most effective tool in this fight. On the other hand, specific measures for fraud prevention (video surveillance, constant surveillance, sudden controls, more detailed employee checking in employment, etc.) with $38.3 \%$ and internal control with $36.3 \%$ share the second and third place in importance for fraud prevention. A very similar number of respondents opted for measures of "higher fines for petty offenses" (26.1\%) and "creating fair business conditions" $(23.5 \%)$, while educating employees about the harmfulness of fraud and ethical principles of behavior is in the last place with only $13.1 \%$. Such answers indicate the respondents' opinion that introducing a stricter penal policy is the best way to prevent fraud and this can be linked to previous results, especially with the questions that considered the forms of fraud where citizens pointed to corruption as the most prevalent for of fraud. This all points to the general attitude that only criminal policy can stop this kind of corruption, or as respondents said, "hitting the wallet". Therefore, it is considered that if you punish someone adequately, it also shows to other persons who are considering the possible fraud that they will not go well. What is a little worrying is that only $13.1 \%$ of citizens think that education on fraud and ethical behavior is a good tool for combating fraud. This is dangerous, because practice has shown that it is precisely through these trainings of company employees and familiarization with possible penalties that many frauds can be prevented. Chart 7 shows the structure of fraud prevention measures.

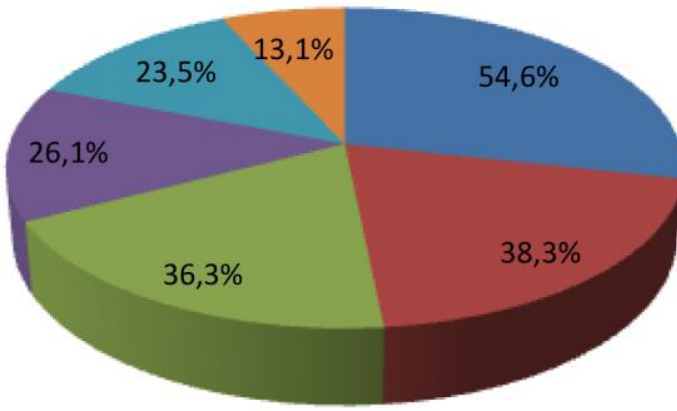

\author{
- Penal policy \\ - Specific measures for \\ fraud prevention \\ - Internal control \\ - Higher fines for petty \\ offenses \\ - Creating fair business \\ conditions \\ aducating employees
}

Chart 7 Fraud prevention measures Source: author's calculation 


\section{CONCLUSION}

Business fraud causes losses not only to companies where they arise, but directly or indirectly, such losses are transferred at some point to the wider community. Whether fraud is "petty" or creates millions of financial losses, it always has a detrimental effect on the economy. For these reasons, it is necessary to detect and prevent business fraud in a timely manner. For this process to be successful, one of the essential elements is to understand the motives that encourage fraud perpetrators. Understanding the motives for committing fraud requires knowledge of the psychology of individuals' behavior. For these reasons, Donald Cressey, a sociologist, conducted a survey in the 1950s by interviewing some 200 people who were convicted of fraud. One of the basic conclusions he draws is that each fraud is characterized by three common factors: pressure (sometimes defined as motivation), rationalization (personal ethics), and opportunity for fraud. Therefore, the main research objective in this paper was to understand the motives of the citizens of the Republic of Serbia that would encourage them to commit possible fraud in business. The survey was conducted by interviewing 306 respondents through surveys distributed electronically.

Survey results indicate that the majority of citizens have never witnessed business fraud (61.8\% of those surveyed) or participated in any type of fraud (75.7\%). On the other hand, more than $50 \%$ of those surveyed believe that financial pressure is the most common pressure factor that would encourage them to commit fraud (55.3\%). The absence of a value system in society is the most important factor that creates opportunities for fraud (54\%), while $25.5 \%$ of respondents consider lack of internal control as an important factor that creates opportunities for manipulation. The previous two results speak to the respondents' opinion about the two elements of the "fraud triangle" (pressure and opportunity), while regarding the third element (rationalization) the citizens believe that two justifications ("I deserve more" and "No one will be hurt") are most used to mitigate the negative elements of fraud. When it comes to the forms of fraud most prevalent in the Republic of Serbia, citizens believe that corruption is by far the most prevalent (57.8\% of those polled), and its highest level occurs in public administration (69.8\% of respondents). Considering the activities of public administration, the respondents identified public enterprises (45.9\%) and healthcare $(25.9 \%)$ as the areas where corruption is most prevalent. Lastly, the results of the survey indicate that the establishment of an adequate penal policy is the best means of preventing fraud, in the opinion of as many as $54.6 \%$ of respondents.

All these results indicate that although the majority of respondents has never taken part directly in any type of fraud, they are still aware that fraud exists (primarily corruption). Respondents believe that public administration, mostly public companies, are most sensitive to manipulation and that close cooperation between state and private control institutions is needed in order to systematically solve the problem of fraud in Serbian companies. This is especially evident in answers on opportunities for fraud where the absence of a value system in society is potentiated as one of the biggest problems that allows manipulation. 


\section{REFERENCES}

Andrić, M., Krsmanović, B., \& Jakšić, D. (2004). Revizija - Teorija i praksa [Auditing - Theory and Practice]. Subotica: Ekonomski fakultet.

Coenen, T. (2008). Essentials of Corporate Fraud. New York: John Wiley \& Sons.

Dimitrijević, D. (2015). Otkrivanje i sprečavanje manipulacija u bilansu stanja i izveštaju o novčanim tokovima [Detection and prevention of manipulations in the balance sheet and cash flow statement]. Ekonomski horizonti, 17(2), 137-153.

Dimitrijević, D. (2018). Forenzičko računovodstvo - instrument otkrivanja $i$ sprečavanja prevara [Forensic accounting - An instrument for detecting and preventing fraud]. Univerzitet u Kragujevcu - Ekonomski fakultet;

Petković, A. (2010). Forenzička revizija: kriminalne radnje u finansijskim izveštajima [Forensic audit: Frauds in the financial statements]. Novi Sad: Proleter.

Slović, J. (2016). Metode i tehnike za sastavljanje i alati za otkrivanje obmanjujućih finansijskih izveštaja [Methods and techniques for compiling and detecting fraudulent financial statements]. In Forenzička revizija p. 93., Retrieved from: http://www.forensic-audit.org/uploads/1/4/6/3/14634014/zbornik_forenzicka_revizija.pdf Accessed on: 16.01.2020.

Singleton, T., Singleton, A., Bologna, J., \& Lindquist, R. (2010). Revizija, kriminalne radnje i forenzičko računovodstvo [The audit, fraud and forensic accounting]. Beograd: Savez računovođa i revizora Srbije.

Stančić, P., Dimitrijević, D., \& Stančić V. (2013). Forenzičko računovodstvo - odgovor profesije na prevare u finansijskim izveštajima [Forensic accounting - the profession's response to fraud in financial statements]. Teme, $37(4), 485-505$.

Stefanović, R. (2000). Sprečavanje i otkrivanje lažnog finansijskog izveštavanja [Prevention and detection of fraudulent financial reporting]. Računovodstvo 11/2000, 3-11.

Škarić-Jovanović, K. (2009). Forenzičko računovodstvo - instrument zaštite interesa računovodstvene javnosti [Forensic accounting - an instrument for protecting the interests of the accounting public]. In: Računovodstvo, revizija i finansije u uslovima globalne krize, Banja Vrućica: Savez računovođa i revizora Republike Srpske, 11-31.

Vukadinović, P. (2018). Modifikacija trougla prevare - novi modeli [Modification of the fraud triangle - New Models]. Revizor, 21(83), 7-19.

Wells, J. (2004). Corporate Fraud Handbook. New York: John Willey\&Sons.

Zabihollah, R. (2002). Financial Statement Fraud - Prevention and Detection. New York: John Wiley \& Sons, Inc.

https://www.acfe.com/report-to-the-nations/2018/default.aspx

\section{STAVOVI STANOVNIŠTVA O OSTVARIVANJU PREVARA U KOMPANIJAMA U REPUBLICI SRBIJI}

Prevare u poslovanju kompanija, bez obzira na njihovu veličini $i$ oblik, stvaraju neki oblik gubitka ne samo za kompaniju već vrlo često i u široj društvenoj zajednici. Takođe, na prevare nisu imune ni najmanje ni najveće kompanije na svetu, u bilo kojoj zemlji, na svim nivoima privrednog $i$ društvenog razvoja kompanije. Iskustva iz prakse su pokazale da prevare, kao i šteta koju izazivaju, su neminovnost. Iz tih razloga veoma je bitan proces sprečavanja i otkrivanja svih oblika prevara u poslovanju kompanija. Kako bi kompanije mogle sprečiti prevare, potrebno je da se razume šta to motiviše ljude da ostvare manipulaciju i načine finansijski gubitak. Mnogi teoretičari navode veliki broj faktora koji mogu da motivišu počinioce prevara na ostvarenje manipulacije, ali se svi slažu da za ostvarenje prevare potrebno je da se poklope tri stvari: motivacija, mogućnosti i opravdanje. Iz tih razloga predmet istraživanja u ovom radu je detaljna analiza svih faktora koji motivišu $i$ stvaraju mogućnosti građanima Republike Srbije da ostvare prevare u poslovanju kompanija, kao $i$ najčešće izgovori koje bi građani koristili kako bi opravdali svoje manipulacije. Anketirano je 306 građana sa ciljem da se analiziraju njihovi motivi za moguće ostvarivanje prevara, kao i njihov stav o brojnosti i oblicima prevara u poslovanju kompanija u Republici Srbiji.

Ključne reči: motiv, prevara, opravdanje, mogućnost, Republika Srbija 